\title{
Tourism: Visit Nepal 2020
}

By Badal, Bharat Prasad

Dr. Badal is visiting faculty of Central Department of Rural Development, T.U. and Editor in chief of Research Nepal Journal of Development Studies. Contact: bpb222@yahoo.com

\begin{abstract}
Tourism is simply selling air in the sky, but putting it in a beautiful balloon. Visit Nepal 2020 is a mega program of Nepal in tourism development. The event has to be a turning point of development of Nepalese tourism. It could be a milestone of Nepalese Tourism in economic transformation of the country. Vision 2020 of tourism ministry has set the vision of two million tourists arrival and one million job creation in Nepal. The vision and the target itself a massive challenge. Meeting the challenge is to create a favorable condition in economy. At this crucial time Nepal has to address the issues of opportunities and challenges. Objectively, to identify the opportunities and challenges of visit Nepal 2020 the study has been conducted. Methodologically the study is a descriptive qualitative analysis of different secondary information depending upon the reviews of different literature. In conclusion the study has revealed the opportunities as the arrival of two million tourists, creation of one million tourism related jobs, advancement of nature and culture, and adventure diversities, linkage with Indian and Chinese economies, development of Public-Private- Partnership models, disaster resilience chances, chances of major tourism development, decentralization of Nepalese tourism, and investment opportunities. Similarly, the challenges revealed by the study are insufficient infrastructures, inadequate investments, limited connectivity and weak national carriers, poor coordination among government agencies, scarcity of resources and marketing. To grab the opportunities Nepal governments, tourism ministries, departments, Nepal Tourism Board and entire tourism stakeholders have to meet the revealed challenges.
\end{abstract}

Keywords: Nepalese Tourism, Opportunities and challenges, Visit Nepal Year 2020

\section{Introduction}

Tourism in Nepal was initiated since the time of composition of Veda around before $3500 \mathrm{BC}$. The scholars and sages used to write holy books with great meditations and penances and used to travel to popularize the findings. Veda was composed in Vyas Municipality of Nepal and 
popularized by many sages all over the south Asia throughout the world. Tourism: Visit Nepal 2020 is in a nutshell, a descriptive qualitative analysis of Nepalese tourism on the perspective of 2020. It is an analysis on developing tourism infrastructure, increasing tourism activities, creating employment in the rural areas and sharing the benefits of tourism in the grassroots level that are also the fundamental assumptions of tourism policies of Nepal. It is an analysis of opportunities and challenges. An opportunity is a situation in which it is possible to do something that is in need to do. Opportunity is a time or set of circumstances that makes it possible to do something. The chances of development are opportunities. Advancement on nature, culture, and adventure diversities of Nepalese tourism; linkage with Indian and Chinese economies; development of PPP (Public, Private, Partnership) model; disaster resilience chances; chances of development of eco, cultural, rural, adventure tourism; tourism decentralization and massive investment opportunities are the specific opportunities of vision 2020 (MOTCA, 2009). Peace, democracy and political stability is prevailed since then.

With the onset of 2020, Nepal is going to launch an ambitious tourism campaign 'Visit Nepal Year 2020 ' with a theme of "Lifetime Experiences". The government plans to welcome two million international tourists by the end of 2020. This seems to be a daunting task but still the target can be achieved because over the last three years, Nepal's tourism industry has been making steady progress (Thapa, 2018). Nepalese tourism was at its lowest ebb after devastative earthquake of 2015. It took the lives of 9000 people and destroyed the property beyond imagination. This was a time when many foreign tourists left the country and several others cancelled their bookings. It caused a severe financial blow to the national economy (Thapa, 2018). However, due to the willpower of Nepal, the nation's tourism has bounced back with renewed vigor and vitality. In 2018, the number of international tourists visiting Nepal increased by 24 per cent as compared to the previous year. The country hosted more than one million foreign tourists last year. Many efforts were made in the past to receive one million international tourists; but it always remained as elusive as ever (Thapa, 2018). However, now things have been changing and tourism has shown obvious signs of growth and development. Achieving the mark of one million tourists has emboldened the self-confidence of the Nepal. Tourism Board (NTB) and tourism entrepreneurs.

This is a herculean task but there is nothing impossible before the highly spirited tourism entrepreneurs of the country. Oxford dictionary defines a call to someone to participate in a competitive situation or fight to decide who is superior in terms of ability or strength is a challenge. It is a call to prove or justify something. A challenge is something new and difficult which requires great effort and determination. A challenge is something that puts to the test 
like running first marathon or reading War and Peace. Challenge, as a verb, is derived from a Latin word meaning "to accuse falsely," and it is still used much as it was in the 13th century, in the sense of questioning whether something is true or right. Challenges are the sources of opportunities. Challenges are the works not done or list of future plan. Limited integration of approaches, limited innovation among stakeholders, limited digital marketing efficiency, brain drain of youths, limited research, development, competitiveness, seasonality etc. are the challenges of Nepalese tourism (MOTCA, 2009). At the time of the formation of vision 2020 in 2009, these points were identified.

To attain the target of two million international tourists in 2020 is challenging. There are numerous hurdles on the way. The road is bumpy, rough and challenging. Lack of budget, resources and security and rampant corruption are some key issues to which the government must pay due attention (Thapa, 2018). Nepal still does not have good air connectivity with major tourist source markets. Although there are being little progress. Currently, 28 international airlines from 14 countries are operating their flights to and from Nepal. However, due to limited space available inside the Tribhuvan International Airport (TIA), its further expansion is not possible (Thapa, 2018). Thus, an additional slot is not possible in the near future. TIA is unable to accommodate more planes and provide additional facilities due to unavailability of more space. Besides, the airport has only earned bad names for its poor services. Even domestic aviation service is not up to the mark (Thapa, 2018). It was believed that Gautam Buddha Regional International Airport would start its commercial services from Bhairahawa before 2020. The construction work is going on slowly. The story of Pokhara Regional International Airport is no better either.

After assessing the present situation, it seems that it may take much longer period to complete the construction of the airport. These two airports can play a key role to attract more international tourists. Lumbini, being the birthplace of Lord Gautam Buddha, can attract many religious tourists. In the meantime, Pokhara is the gateway to the Annapurna region, a popular trekking destination. A direct flight to Pokhara can encourage more tourists to visit this beautiful city for trekking and other purposes. As a worldwide export category, tourism ranks third after chemicals and fuels and ahead of automotive products. In many developing countries, tourism is the top export category as Nepal too. Nepal has invested huge amount of finance in agriculture and education of Nepal but its outcome is not significant. Only tourism can justify the outcome of the investments because it is simply the course of community development through tourism.

\section{Review}


A good place to live is a good place to travel. MOTCA (2009) defines "Tourism is valued as the major contributor to a sustainable Nepal economy, having developed as an attractive, safe, exciting and unique destination through conservation and promotion, leading to equitable distribution of tourism benefits and greater harmony in society" (MOTCA, 2009, p. 3). Thus the document has set the goals to increase annual international arrivals to Nepal to two million by 2020 and to expand economic opportunities and increase employment in tourism sector to one million by 2020. Nepal Rastra Bank report shows total foreign currency exchange (less return) for 2018 stood at Nrs. 69,750,584 thousand, (Around 617,263 thousand US\$). This is almost 17\% higher than previous year 2017 in USD. There is less increase in currency compare to tourist arrivals results decreased in per tourist per day expenditure at 44 USD which is $18 \%$ less than last year (MOCTCA, 2019). The differences in the decade is positive although in mid it has to suffer from massive earthquake.

Modern Tourism in Nepal was started with the camping accommodation since the very beginning of the 1950s when Maurice Herzog and his team scaled Mt Annapurna on June 3, 1950 and Tenzing N Sherpa and Edmund Hillary first ascended Mt Everest in 1953. The formal growth of accommodation facilities in Nepal started with the establishment of 'Royal Hotel' by a Russian national, Mr. Boris Lissanevitch, in February 1955 (Shrestha \& Jeong, 2016). However, the planned development of tourism in Nepal started after 1956 with the starting of the first five-year plan (1956-1961 AD) and subsequent establishment of Tourist Development Board in 1957 under the Department of Industry. Nepal has always promoted tourism from 1956 onwards and Nepal Tourism Board has taken initiatives from time and again to organize collaborative ventures with government, private and regional forums. It has continued its efforts to help attract major events to Nepal in order to assist growth of business tourism, to increase the use of customer database in order to engage into customer relationships marketing and finally to create a confidence and desire among the trade and the final consumers.

Nepalese plan development has not yet identified it is a strong back bone of Nepalese economy. The different plans had different approach towards tourism but none of the plans talked about technological development till 1992. In 1992 the eighth five-year plan (1992 - 1997) was the first plan that put tourism as a center of all economic activity, the plan talked about technology and its role in tourism but it failed without any outcome (Shrestha \& Jeong, 2016). By achieving the goals, the tourism improves livelihoods of the people across the country by developing integrated tourism, infrastructure, increasing tourism activities and products, generating employment in the rural areas enhancing inclusiveness of women and other deprived communities, and spreading the benefits of tourism to the grassroots level (MOTCA, 2009). Similarly to develop tourism 
as a broad-based sector by bringing tourism into the mainstream of Nepal's socioeconomic development, supported by a coherent and enabling institutional environment, to expand and extend tourism products and services in new and potential areas of Nepal by enhancing community capacity to participate in tourism activities, to publicize, promote and enhance the image of Nepal in international tourism source markets, to enhance the flight safety and aviation security, extend air connectivity, and improve capacity and facilities of national and international airports and to attract new investment in creating new tourism facilities, products and services the plan has been developed and implementing.

In such a condition as well he gross value added of hotel and restaurant sector, which expanded by 7.3 percent in FY 2016/17, is estimated to grow by 9.8 percent in the current FY 2017/18. This sector experienced the growth in its production due mainly to the increase in number of tourist's inflow along with the promotion of domestic tourism, undisrupted supply of electricity and infrequent general strikes. The contribution of hotel and restaurant sector to GDP is estimated to remain at 2.0 percent in the current FY 2017/18 (MOF, 2018). Tourism is the largest industry and one of the key sources of foreign exchange in Nepal. Nepal is a unique destination for mountaineering, trekking, rafting and jungle safari. It possesses eight out of 10 highest mountains in the world. There are 10 world heritages and unbeatable combination of natural beauty and cultural riches. In 2018, it welcomed around 790 thousand tourists and earned about 472 million US dollar as an income from tourism (NPC, 2019).

Out of total tourist arrivals, five countries occupy almost 50 percent. The proportion of tourists from these countries are; India (16.57\%), China (13.1\%), USA (7.83\%), Srilanka (5.94\%) and United Kingdom (5.41\%) respectively. Similar seasonality exists in tourist arrivals as in previous year. The highest number of arrival is observed in November followed by March. There is no major change in sex and age group of tourist arrivals. By sex male $(53.3 \%)$ and about highest percentage of arrivals were of age category 31-45 (30.7\%) in year 2018 (MOCTCA, 2019). Three-year development plan (2016-2018) aimed to increase the length of stay to 14 days by 2018. It was ranging from 8 to 13.5 days in the past. The analysis of length of stay of $6,53,605$ tourists estimated it as 12.4 days in the year 2018. Historical data showed more than 60 percent of the tourist arrived with purpose of holiday celebration and pleasure.

Year 2018 showed higher proportion (60\%) visited Nepal for holiday and pleasure followed by adventure including trekking \& mountaineering (16\%), pilgrimage $(14.4 \%)$ and other purpose $(9.6 \%)$. Nepal is famous destination for pilgrimage due to its prominent, glorious and prideful historical and sacred places. Lumbini, being birth place of Lord Buddha and Pashupatinath, a 
center of faith for Hinduism is major among many important places. Lumbini is found as most visited pilgrimage by foreigners. It was visited by $1,517,134$ persons out of them $76.2 \%$ were Nepalese while $12.7 \%$ Indians and $11.2 \%$ from other countries. Similarly, the 163,311 visitors form third country visited the Pashupatinath (MOCTCA, 2019). The foreign currency equivalent to Rs. 58.5270 billion was earned through the tourism sector in the FY 2016/17. The ratio of this amount is 71.3 percent to the total foreign currency earned through total export of goods, 24.3 percent to the total foreign currency earned through total export of goods and service, 5.1 percent to the total foreign currency earned and 2.3 percent to Gross Domestic product (MOCTCA, 2019).

From global perspectives, the World Travel \& Tourism Council's (WTTC) research reveals that the sector accounted for $10.4 \%$ of global GDP and 319 million jobs, or $10 \%$ of total employment in 2018. The division of overall spend is firmly weighted towards the leisure market, which represented $78.5 \%$ of the total compared with $21.5 \%$ for business spend, and the sector accounted for $6.5 \%$ of total global exports and $27.2 \%$ of total global service exports. Domestic tourism, which represented $71.2 \%$ of all tourism spending in 2018 and had the strongest growth in developing nations, continues to support opportunities by spreading development and regional economic benefits and building national pride (WTTC, 2019).

\section{Objectives and Methodology}

The study has been conducted to find out the tourism history, status, opportunities and challenges of mega events of visit Nepal 2020. The study is simply literature review as a qualitative descriptive analysis of opportunities and challenges of the visit Nepal 2020. The study used publicly available data published by the, National Planning Commission, Tourism Ministry, Finance Ministry, World Bank, Nepal Tourism Board (NTB) and like such. Tourism is only a means to transform Nepal.

\section{Discussions}

Tourism stimulates the economy. Tourism empowers both public and private bodies to make sound economic decisions that can support sustainable and inclusive growth and provides the comparative evidence to analyses the impacts. As a result, governments across the world are better able to strategically plan and develop more effective policies, enhance their decisionmaking relating to investment, and further cooperate with the private sector to ensure the Travel and Tourism sector provides the greatest opportunities for societies to prosper. In Nepal, tourism is the second largest industry after agriculture. Furthermore, Nepal offers numerous opportunities 
for adventurous outdoor recreation, especially in the Himalayas, and attracts tourists from all over the World (Pokharel, Poudel, Sharma, \& Grala, 2017). Results show that the number of international tourists visiting Nepal was remarkable. Visit year celebration is a program designed to boost the tourism industry, was started from 1998 in Nepal.

Many tourism related products and services are based only on the aforementioned existing natural or cultural/historic promise, most of which do not have acceptable marketing support in forms of infrastructure, amenities, and digital communication to optimize the tourist experience, and to alert potential and actual tourists of the existence and nuances of those experiences (Shultz, Pestek, \& Geroulis, 2015). An obstacle is the lack of understanding or appreciation for the role that destination-management organizations must play at all levels and throughout the marketingsystem required for a thriving tourism sector. Visit Nepal 2020 is mega event to improve the quality in tourism. Current policies and practices reveal ineffectual and inefficient - and often uncompetitive - management across the marketing mix for touristic goods and services throughout the country. Thus local governments have to take initiatives. Nepal has 852 species of birds and bird watching has evolved into a sought out activity of tourists. Nepal also homes several endangered species such as the Bengal Tiger, One Horned Rhinoceros, Bengal Fox, Red Panda and the elusive Snow Leopard (Pokharel, Poudel, Sharma, \& Grala, 2017). The local governments must be able to grab the opportunity on the decentralization of Nepalese tourism.

Proper holistic planning and implementation of actions; development of new attractions, products and services; local public private partnerships; investments in basic infrastructure and tourismspecific infrastructure; identifying and developing target markets; market intelligence; quality management; easier access to finance for tourism establishments; hospitality and services-related education and so on, all are vital to the well-being of tourist-consumers, the tourism industry (Shultz, Pestek, \& Geroulis, 2015). As the study explains Nepalese tourism has the same challenges.

Similarly, environmentally, tourism has provided protection to the natural environment through financial contribution from entrance fees and the maintenance and enhancement from government funding. The financial contribution from tourism has provided for the management and expansion of protected areas (Bhola-Paul, 2015). Tourism is a significant export product for nation and contributes economically to the island through its GDP, the employment it provides, and the number of cruise calls made by the excursionists and the foreign tourist stop-over arrivals. However, the case of Nepal is little bit different. Some of the role or importance of the Tourism industry to Economic Development in Nepal are following points: Source of Foreign Exchange Earning, 
Exchange of Art and culture, Increase in Employment opportunities, Increase in Government Revenue, Development of cottage and small scale industries, Development of infrastructure, Increase in Social facilities, Conservation of Natural Resources, Human Resource Development. These are the burning issues and could be the point of departure.

Tourism is a social development phenomenon that also covers and stimulate economy. Tourism is much more than an economic sector, it is also a social, cultural, political, and environmental force that drives societal change. Understanding, responding to, and managing this change will inevitably require knowledge among the workers who are able to address a range of problems associated with tourism, travel, hospitality, and the increasingly complex operating environment within which they exist (Bajracharya, 2018). Tourism is a tool of community development.

\section{Opportunities}

1. The Arrival of two million tourists around the world

It is a great opportunity. Nepal has great opportunity to welcome the two million tourists as targeted in 2015. The Tourism Ministry had planned to celebrate Visit Nepal Year in 2018, which was put off due to the delay in construction of airports, heritage sites and roads. It has given due priority to the early completion of the construction and expansion of the international and domestic airports, heritage sites and other tourism infrastructure. The government has planned to complete the expansion of Tribhuvan International Airport and construction of Gautam Buddha Airport in Bhairahawa before the Visit Nepal Year. Likewise, the reconstruction of major heritage sites is expected to be completed before 2020. Government of Nepal surely indicates a double digit growth rate in the number of tourists' arrival in Nepal in the past year of 2017. However, the quandary remains that is the growth rate of $25 \%$ as compared to that of $40 \%$ in the year 2016 that clearly reflects a deficit of $15 \%$ within a period of last one year a merry situation while discussing the strategies to promote and upgrade the industry to meet the vision of Visit 2020 to welcome 2 million tourists within the time period (Mahato \& Khanal, 2018). Atithi devo bhwa guests are god in Nepal so if we get chance to please 2 million gods the blessing will be economic boost up. It will be the major boost to Nepal tourism sector of 150,000 Chinese tourists, by air visit Nepal in 2018 as expected, according to NTB. Nepal received a total of 104,664 Chinese tourists in 2017, according to Nepal's Department of Immigration. China is the second largest source of foreign tourist to Nepal. Over one lakh Chinese tourists visit Nepal annually. China has designated Nepal as the first tourist destination in South Asia for its people. The Government of Nepal has waived visa fees for the Chinese tourist effective from $1^{\text {st }}$ January 2016 (Dahal G. , 2018). Investment in tourism sector is of long-term nature and that it may not bring immediate 
benefits to the people.

2. The Creation of one million tourism related job in Nepalese Economy

Only job creation gives the vive to the economy. While welcoming two million tourists it needs almost one million direct and indirect human resources. The government believes that, with the launch of this ambitious campaign, the country will lead in the sector of tourism providing job opportunities to over one million people all around the country. Engagement of locals in this field can help them improve their livelihood as well. This campaign is aimed to be run in major international cities by collaborating with airlines, private sectors or national and international organizations. India is Nepal's largest trade partner and the largest source of foreign investments, besides providing transit for almost entire third country trade of Nepal. India accounts for over two-third of Nepal's merchandise trade, about one-third of trade in services, $36 \%$ of foreign direct investments, almost 100\% of petroleum supplies (Dahal G. , 2018). Around 6, 00,000 Indian nationals have been living in Nepal and around 10,00,000 Nepalese nationals have been working in different parts of India. China is the second largest trading partner of Nepal. In 2015/16, total exports to China stood at US\$181 million with marginal increase from US\$179 million in the previous fiscal year. In contrast, import from China has been growing at the rate of 39 per cent per year. It rose from US\$421 million in fiscal year 2009/10 to US\$1,247 million in fiscal year 2015/16. Although China has given zero tariff entry facility to over 8000 Nepali products that starts from 2009, Nepal exports only 370 products including noodles and agro products to China (Dahal G. , 2018). Only tourism and economic diplomacy can increase the job numbers.

New investments have helped create $1,027,000$ new jobs in the country of which 497,500 are directly involved in the tourism industry, the report shows. The direct employment includes employment generated by hotels, travel agents, airlines and other passenger transportation services, and restaurants as well as leisure industries. New jobs created by the tourism industry in 2017 is 6.6 percent of the total jobs created in 2017 (Magar, 2018). In the year 2016, new investments had created 945,000 jobs, including 427,000 people in the tourism sector. As the government has considered tourism, agriculture and hydropower as the backbone of country's economy, increasing investment in tourism industry country is a good sign for the economy, tourism entrepreneurs say (Magar, 2018).

3. The Advancement of nature, culture, and adventure of Nepalese tourism

Nepal is a country of nature, culture, and adventure. Welcoming visitors to celebrate the year 2020, is chosen as national tourism year of Nepal after the year 2011 which was the primary authority 
tourism year of new Nepal. The government and tourism department of Nepal authoritatively reported that Nepal will take year 2020 as "Visit Nepal 2020", a year committed to tourism industry of Nepal with vision of making a reasonable brand picture of Nepal as travel and vacationer destination, backing up the tourism foundations of Nepal, enhance the growth of tourism industry, and enhance locale tourism as supportable industry. The legislature has wanted to accommodate more than one million visitors amid the year of "Visit Nepal 2020". Since Nepal has a history of standing as a rare bridge between India and China, in present times, the number and types of interactions is increasing-culture, politics, security, trade, tourism, investment-rather than diminishing. In this context, it is worth examining the potential of trilateral arrangements or the "Bridge" discourse to synergize the current bilateral India-Nepal, China-Nepal and India-China relationships (K.C. \& Bhattarai, 2018). Nepal can be transformed simply demonstrating nature culture and her massive awesome adventure. The event of Visit Nepal 2020 will be the milestone of Nepalese economic development.

\section{The Connectivity and Linkage with Indian and Chinese economies}

For Nepal, the Belt and Road Initiatives (BRI) will a potential lifeline from Chinese perspective. MCC will be another mega opportunity from Indo Pacific strategy. A landlocked nation long dependent on India's favor sees a planned Chinese rail route across the mountains, begun in 2013, as an economic boom-and a vital counterweight against India's economic power (Budhathoki, 2019). China officially included the Nepal-China Trans-Himalayan Multidimensional Connectivity Network in its joint communique of the second Belt and Road Forum in Beijing. Deals inked during Chinese President Xi Jinping's recent visit to Nepal may push the project forward, giving Nepal, previously shortened in by India, far better options (Budhathoki, 2019). China wants to invest in big connectivity projects in Nepal but prefers to bring its Asian competitor, India, on board. Some Nepali and Chinese scholars see this as an opportunity for trilateral cooperation between Nepal, India, and China, but Indian policymakers and academics have not shown much interest (Bhattarai, 2018). Because of the open-border system between Nepal and India, the people-to-people relations among the border inhabitants of the countries in social, cultural, economic and a diversity of other fields have remained unparalleled in world history. The border between Nepal and China is largely sealed and as such the border inhabitants among the two countries have not been able to obtain adequate benefit at the local level.

It is likely that the border inhabitants living along Nepal's border regions with India and China would benefit more if connectivity is developed between the two sides of the border through roads, irrigation, communication and other infrastructural facilities (Jha, 2013). In order to safeguard 
Nepal's national interest, the country has to take all possible precautions to ensure that the interest of one neighbor is not affected by the other, while avoiding further rivalry between them. The lonely planet reports somewhere, in 2014 Tribhuvan was voted the third worst airport in the world. This is actually more than a little unfair as there are lots of worse international airports but they're just not ones visited by many international tourists. A new international airport is under construction in Pokhara and due to open in July 2020. Work is also under way to transform Bhairawa airport into an international airport by 2019. An even larger airport, capable of handling the A380, is planned for Hetauda. All three of these projects have experienced significant delays. Nepal has to think on the issues raised by Lonely planate.

5. The Development of Public, Private, Partnership Model of Tourism Development

Nepal is the country of brave hard working people. The development of tourism in emerging economies have been shaped by many factors among which Public-Private Partnerships (PPP) play a key role as they bring together government agencies and the public sector with representatives of the whole tourism value chain under the same goals of promoting socioeconomic development, sustainability, job creation and international competitiveness through tourism (WTO, 2015). PPPs bring together stakeholders with different objectives and skills, and resources in a formal or informal voluntary partnership to improve the attractiveness of a regional destination, its productivity, associated market efficiency, and the overall management of tourism. In this report, we discuss PPPs that target improvement in many aspects necessary for successful tourism such as transportation, events, accommodation, attractions, business skills and resource protection. Hence, PPPs are important, and often vital, elements in the establishment of tourism based initiatives and the improvement of the market competitiveness of destinations.

Tourism sector is one of the cornerstones of economic developments for most countries and a gate which integrates countries to international markets. Almost every country targets to host a greater number of foreign visitors every other year. Tourism projects generally require a high amount of initial investment for which the private financing may become impossible for most companies. Public Private Partnership (PPP) could be suggested as a viable model to finance tourism projects where tourism projects are financed and operated through a partnership of government and one or more private sector companies. This research study conducts a comparative analysis of risk transfer and cost reduction effects on various PPP models for tourism projects financing. The features of structuring a PPP model is proposed and applicable areas in tourism services are discussed, an application of the proposed model is utilized. The findings support that all parties gain something which presents a win-win case (Teker \& Teker, 2012). Entrepreneurs poured 
more money to build hotel and resorts, and buy new aircraft for 2020 (Magar, 2018).

\section{The Earthquake resilience opportunity}

The earthquake in 2015 had havoc mess. Since the shocking earthquake of 2015 Nepal has energetically fixed and modified landmarks, streets, settlement, and other frameworks. The tourism industry is presently back to pre-tremor levels. Almost around a million people visited Nepal in 2017. It is presently the fifth-most-famous tourism destination and number one best worth destination in the world. Nepal boasts unspoiled natural beauty, sky-high Himalayas Range and different but never-ending culture and traditions extend out all over the nation (Shrestha \& Jeong, 2016). Disasters can turn as dark tourism. Narayanhity Royal Palace, Maoists' War, the earthquake can be developed as Hiroshima and Nagasaki of Japan through the development of dark tourism. Millions of people visit Hiroshima and Nagasaki every year. Nepal must be able to finalize the reconstruction activities arose from the devastating earthquake of 2015 before the 2020. Destination marketing refers to a management process through which the national tourist organizations and/or tourist enterprises identify their selected tourists, actual and potential, communicate with them to ascertain and influence their wishes, needs, motivations, and likes and dislikes, on local/rural, regional, national and international levels, and to formulate and adapt their tourist products accordingly with a view to achieving optimal tourist satisfaction, thereby fulfilling their objectives. Thus those areas can be developed as tourists' destination.

\section{Chances Tourism Development in Nepal}

It is a chance to grab the 2 million tourists. The government has planned to develop new products which are divided into 5 clusters; i.e. Culture, Cities and Leisure, People and Heritage, Outdoor and Adventure, Religion and Pilgrimage, and Nature and Wildlife (Bajracharya, 2018). To develop and promote all these sectors, one major hub for tourism will be marked and selected in every region where facilities like home-stays, community-based products will be boosted. The major emphasis will be given to infrastructural development like food, shelter, and clothing along with other secondary needs. Specifically, sustainable tourism products are "understood broadly as meaning those that use resources in an environmentally responsible, socially fair and economically viable way, so that users of the product can meet their current needs without compromising future generations from being able to use the same resources. Measuring sustainability is a complex issue and the criteria vary according to the product type and local conditions. Deciding what is ultimately sustainable for a particular community is a balance between local circumstances and expectations and best practice in technology and environmental management. Following types 
of tourism can be developed.

\section{Major Types of Nepalese Tourism}

- Natural Tourism: exploring conservation areas by walking or riding in the forest, or on the mountain or beach, navigation in rivers, lakes and the sea, observation of flora, fauna and other natural attractions such as mountaineering, trekking, hiking, cycling, paragliding, sightseeing, waterfalls, caves, cannoning, flora and fauna, bird watching, jungle safari including entire adventurous tourism in Nepal.

- Cultural tourism: living with native communities, including participation in daily life activities and various cultural events, such as music, dance and arts, rites or religious holidays, festivals, lifestyles, livelihood, through rural tourism like home stay and farm stay.

- Agro-Eco-Tourism: visiting rural communities to participate in agricultural production, livestock, handicrafts other traditional agricultural activities. Tourism related to Environment protection and sustainable development.

- Historical tourism: visiting special sites to see monuments, sculptures, architecture, civil, military or religious artefacts, archaeological remains of ancient cultures, local museums and sites of paleontological interest. The UNESCO world heritage sites are: The cultural heritage of the Kathmandu Valley is illustrated by seven groups of monuments and buildings which display the full range of historic and artistic achievements for which the Kathmandu Valley is world famous. The seven include the Durbar Squares of Hanuman Dhoka (Kathmandu), Patan and Bhaktapur, the Buddhist stupas of Swayambhu and Bauddhanath and the Hindu temples of Pashupati and Changu Narayan. Similarly, other one is Siddhartha Gautama, the Lord Buddha, was born in 623 B.C. in the famous gardens of Lumbini, which soon became a place of pilgrimage. Among the pilgrims was the Indian emperor Ashoka, who erected one of his commemorative pillars there. The site is now being developed as a Buddhist pilgrimage center, where the archaeological remains associated with the birth of the Lord Buddha form a central feature.

- Health Tourism: today, increasing interest in fitness, disease prevention, maintaining good health, new age remedies and alternative treatments to alleviate various types of stress are key tourism motivators. Such tourism may include visits to holy sites with communities; participation in rituals and treatments with healers and shamans. Animism and Shamanism are still in good practice in Nepal. It is practice of travelling across international borders to 
obtain health care. People from Bhutan, Bihar, West Bengal, Utter Pradesh are still visiting in Nepalese Hospitals.

- Religious Tourism: also commonly called "faith tourism", this involves travel for reasons of faith, for pilgrimage, missionary and other related purposes. Once in a life time a Vedic or Buddhist must visit Pasupatinath and Lumbini of Nepal. It is mention in their respective holy books.

- Sports Tourism: recreational fishing and hunting, sports that require specialized training and equipment: canoeing, climbing, Elephant polo, paragliding competition etc. are very famous in Nepal.

- Scientific Research Tourism: observation and study of flora, fauna and geology, local food plants and ancestral medicinal knowledge and its applications in the conservation of biodiversity.

- MICE and Education Tourism: The term "MICE" in the context of travel is an acronym for meetings, incentives, conferences, and exhibitions. The MICE market refers to a specialized niche of group tourism dedicated to planning, booking, and facilitating conferences, seminars, and other events, which is a big moneymaker in the travel industry. Nepal is suitable for training and workshop in all seasons with pleasant weather. People around the globe can visit and organize the program here in Nepal (Pokharel, Poudel, Sharma, \& Grala, 2017).

\section{Tourism Decentralization}

Nepalese tourism must cover entire Nepal. Tourism in Nepal seems that is located only on Kathmandu valley, Chitwan, Kaski and Annapurna and Sagarmatha region. Here, 753 local governments 7 provincial governments and 1 federal governments total 761 governments are functioning in Nepal. Its impacts can be noticed soon. Entire 761 governments are working with high effort to produce the result of development. Every center of local government can be the holiday hub for Indian and Chinese people. Tourism mechanisms have an opportunity to expand it from every village of Nepal. Tourists must visit as much as more destinations and live as longer as they live 14 days in average in Nepal. Marketing is a process through which individuals and groups provide, exchange and obtain products - ideas, goods and services - capable of satisfying customers' needs and desires at a desirable price and place. Marketing requires a strategy. It is an all-encompassing, planning, scheduling, studying, figuring-stuff-out, researching, testing, and practicing strategy Destinations are places that attract visitors for a temporary stay, and 
range from continents to countries to states and provinces, to cities, to villages, to purpose built resort areas. At the foundation level, destinations are essentially communities based on local government boundaries. Tourists travel to destinations. Destinations are places with some form of actual or perceived boundary, such as the physical boundary of an island, political boundaries, or even market-created boundaries. Every village can be developed as a destination with special features. The fundamental challenge is to somehow develop a brand identity that encapsulates the essence or spirit of a multi-attributed destination, representative of a group of sellers as well as a host community. Tourism marketing is generally concerned with the selling of dreams, as expectations of an intangible tourism service can only be realized after travel. The images held by consumers therefore play a critical role in their decision-making.

\section{Investment opportunities in Tourism Sector}

In the recent years, Nepal has made great strides towards attracting private sector investments. The Investment Board, chaired by the Prime Minister, was established in order to fast track large investments and act as a one-window facilitation agency. Similarly, Nepal is in the process of amending various laws and regulations to make them more investment friendly. In an effort to attract investment, Investment Board Nepal, with the support from Ministry of Industry, has produced "Nepal Investment Guide". Building on to this initiative, the Investment Board has again taken lead to come up with this publication (Magar, 2018). This document highlights sectorspecific opportunities for investment, policy environment, incentive structures, and licensing processes. This sector profile has been produced at a very opportune time as Nepal embarks on the path of economic transformation. Investment promotion is the process (set of means and actions) designed to inform potential investors/visitors about the tourism product offered, sharing with them its most attractive and innovative attributes. As such it is usually integrated with distribution and implies communication activities, including advertising.

Nepal is a great Himalayan Country and located in between two emerging economic giants, India and China, and unique access to their market. Nepal has huge potential of growth and untapped natural resources. Nepalese Government has liberal rules for investment including foreign investment. Nepal also has developed easy in repatriation of foreign exchange. Unlike in other countries Nepalese government made policy of lower tax rates especially for industries and Nepalese Government is a small and accessible government. The Nepalese Kingdom has made open and liberal export/import rules. Nepalese People are hardworking and affordable man power. The newly elected government is dedicated to maintain human rights and easy relation with international community, and also committed to get foreign investment in a professional 
way. The country has huge potential for Hydropower, agriculture, and mining investment and is close to India and China (Dahal B. K., 2018). Nepal is a truly unique country and is a home to many large temples and monasteries. It is pretty easy to carry out a business endeavor in Nepal. The major reasons are: Nepal has ranked $2^{\text {nd }}$ after Sri Lanka among the South Asian countries which are the easiest to work in. Nepal offers $100 \%$ FDI in various sectors. There is the chance of a bilateral investment protection and double tax avoidance arrangements in Nepal. Nepal has located between two largest growing economies of the world, India, and China. Nepal has duty free access to China for more than 4000 products, so the ease of importing products is a major contributing factor. Nepal also has duty free and open border access to India. The biodiversity and abundant water resources available in this country are rich

\section{Challenges}

\section{The Insufficient Infrastructures}

Nepal must focus in infrastructure development. Nepal has not yet started new airports. The road is bumpy, rough and challenging. Lack of budget, resources and security and rampant corruption are some key issues to which the government must pay due attention (Thapa, 2018) before the starting of 2020. Nepal still does not have good air connectivity with major tourist source markets. Currently, 28 international airlines from 14 countries are operating their flights to and from Nepal. However, due to limited space available inside the Tribhuvan International Airport (TIA), its further expansion is not possible (Thapa, 2018). The government has also planned to bring two more international airports in Nepal; Gautam Buddha Airport in Bhairahwa and Pokhara International Airport in Pokhara. Construction and management processes are going on full pace along with maintenance of Tribhuvan International Airport and different local airports. Land transportation linking the neighboring countries, India, China, Bhutan, and Bangladesh will also be improved. Thus in the short span of time it is challenging to develop the tourism infrastructures. A divided society with political instability, problems with laws and orders, inadequate infrastructure development, poor management of its lucrative tourism sector and labor unionism, all factors hinder the proper economic growth of our nation. Nepalese government, planners and policy makers must study how the country could 'catch up' with its fast growing neighbors under the given constraints (K.C. \& Bhattarai, 2018)

\section{Insufficient Investment in Tourism}

Nepal needs to increase investments in tourism sector. Nepal is classified as a least developed country (LDC) by the United Nations, its goal is to graduate from this status by 2022 and 
transition to a middle income country by 2030 . To achieve these targets, an economic growth rate of 7-8\% and investment in infrastructure of USD 13-18 billion by 2020 will be required (Teker \& Teker, 2012) (Dahal, 2018). The Ease of Doing Business Index 2017 by the International Finance Corporation (IFC), World Bank Group places Nepal second only to Bhutan among all South Asian countries Nepal's investment potential, combined with these feature, have led to an increase in interest in FDI in recent years. Nepal has increased the level of doing business index in the year of 2019. Although Nepal has challenges to develop a tourism promotion investment project bank. The report, entitled Travel and Tourism Economic Impact 2018 published by World Travel and Tourism Council (WTTC), shows total investments in tourism sector reached Rs 17.3 billion in 2017 compared to Rs 16.5 billion in 2016. Total investment in tourism sector in 2017 was 2.3 percent of the total investments in the country. The council estimates investments in Nepal's tourism sector to increase by 7.6 percent in 2018 and by 4.7 percent annually over the next decade to reach Rs 29.4 billion in 2028 .

3. Limited connectivity and weak national carrier

Nepal must apply RBI (Road and Belt Initiatives) of China and MCC (Millennium Challenge Corporation) of Indo pacific plan strategically. The Himalayan mountains have historically been a barrier between Nepal and China, but railways, roads and tunnels are about to change that. In the battle between geography and technology, Nepal will fall into the Chinese embrace if technology wins. If geography remains a factor however, India can continue to wield political, strategic and geopolitical influence on Nepal (Thapa, 2018). The idea of political geography will come into play around the trilateral relations between China, India and Nepal. Relationship between Nepal and China can be traced back to the seventh century. Around 600-650 BC, Nepali princess Bhrikuti was married to the Tibetan Emperor Songsten Gampo. Princess Bhrikuti took Buddhists relics and Thangkas to Tibet, and established Buddhism in Tibet. Since that time Nepal and China started importing and exporting sculptures and paintings. The cooperation between China and Nepal was further strengthened by the joint efforts of both sides. The two countries have cooperated constructively in various fields. The two sides are in a bid to further strengthen the cooperation through China's Belt and Road Initiative (Dahal, 2018). The two sides have signed a number of cooperation agreements, including the Economic and Technical Cooperation Agreement. China is Nepal's important development partner in the areas such as infrastructure, power development, communication, agriculture and technology, education and culture, tourism and aviation, capacity building, health, people's livelihood, disaster prevention and mitigation, and cultural heritage renovation.

India and China are two very populous countries with ancient civilizations and a time honored 28 
history, which dates back 2,000 years, and since the establishment of diplomatic ties between two countries, friendship and cooperation have made significant progress (Dahal, 2018). China is India's largest trading partner in the world and India is China's seventh largest export destination. Many Indian projects in China are focused in sectors such as automobiles, energy, computer accessories, machinery, telecommunication and export of steel. Similarly, more than 100 Chinese companies operate in India. Many Indian banks and Chinese banks have branches in each other's countries. Although Nepal India and China needs to develop a new avenue and the center of tourism holiday hub Nepal.

\section{Weak Coordination among Government Agencies}

All over the globe and in Nepal as well, tourism is very sensitive business and very volatile and vulnerable. A single bad event can destroy its entire history of tourism. The Weberian model of bureaucracy in the country is for strengthening democracy and establishing justice (Chhetri, 2018). The Middle class people, (consist of bureaucrats; employees of nonprofit organization; lawyer; medical workers, businessmen, academicians and so on), are the friends of democracy, are champion in bending and breaking the rules and regulations and constitution. The attitude and behavior of bureaucrats are more appropriate to the traditional political system. In such a society, it is difficult to transplant the rule of law. Several study findings have noted "no rule of law, no democracy". Modern bureaucracy in Nepal, in this sense, is ill suited, it has lost its relevancy. Mal-governance and mal-redistribution has been contributing corruption everywhere (Chhetri, 2018). Constitutional bodies are not independent to carry out their functions independently due to politicization of state institutions. Similarly, the national corruption control agencies lack the power to crack down malpractices. In a democratic republic system, citizens enjoy a number of basic civil and political rights Human rights and liberties spelled out in the constitution (Chhetri, 2018). The bureaucracy of Nepal has to play an improved good governance based administrative roles. They must prove themselves transparent, accountable and responsible to deal with people and tourists.

\section{Ineffective Marketing}

Scarcity of resources for aggressive publicity and consumer promotion is urgent. Nepal has not managed yet any specific model for tourism marketing. To market anything it has to develop product first and it is only marketing mountains and Lumbini. Aggressive publicity is necessary. Cristina Jonsson of University of West Indies defines, Tourism is unique among industries and the application of marketing principles to the industry need to address at least seven important sub-sectors or dimensions; travel, transportation, accommodation, food-service, tour operators, 
attractions and merchandisers. The marketing activity needs be multifaceted and directed toward a number of customer targets. Tourists are customers.

Making the statue of Rahul Sankrityayan can be an effective marketing of tourism around the socialists and Buddhists community around the globe (Badal, 2019). A tourist is typically characterized as a mobile, amorphous individual with disposable cash motivated by a need to have as good time holiday. In reality they must be defined in terms that reflect their peculiar characteristics and psych-socio profiles. Marketing research is extremely important to the creation of strategies for tourism marketing. All strategies begin with an understanding of the customer that then leads to relating, perhaps modifying the product as to the destination environment, the type of food service, the design of accommodations and even the travel and destination mix, to customer profiles. Therefore, it needs massive effective program. It needs some more research and development.

\section{Conclusion}

Tourism industry is important in an economy for the benefits that it brings and due to its role as a commercial activity that creates demand and growth for many more industries. Tourism industry is recovery of any other industry. Tourism not only contributes towards more economic activities but also generates more employment, revenues and play a significant role in development. In addition to the revenue, there are also fantastic cultural advantages. It can be a source of pride for local communities, and allows them to look at their history, and cultural heritage and develop their own community identity. In simple tone tourism helps to develop the economic condition of a country as it helps to earn foreign currency. As the tourist visit different places of Nepal, they also come across and get to know about culture by seeing different dances, hearing different songs, and celebrating festivals. Thus tourism is integral part of national development.

Tourism must be joined with any program. In conclusion the study has revealed the opportunities as the arrival of two million tourists, creation of one million tourism related jobs, advancement of nature and culture, and adventure diversities, linkage with Indian and Chinese economies, development of (Public-Private- Partnership) PPP models, disaster resilience chances, chances of major tourism development, decentralization of Nepalese tourism, and investment opportunities. Similarly, the challenges revealed by the study are insufficient infrastructures, inadequate investments, limited connectivity and weak national carriers, poor coordination among government agencies, scarcity of resources and marketing. To grab the opportunities Nepal governments, tourism ministries, departments, Nepal Tourism Board and entire tourism 
stakeholders have to meet the revealed challenges. The future of Nepalese tourism is satisfactory.

\section{References}

Badal, B. P. (2019). Roles of Rahul Sankrityayan in Nepalese Cultural Tourism. Research Nepal Journal of Development Studies, , 13-21.

Bajracharya, R. (2018). Tourism Education and Nepal MountainAcademy:A Critical Debate. Voice of Himalaya Nepal Mountaineering Association Year 7 volum 1, 15-20.

Bhattarai, K. D. (2018). The China-India- Nepal Triangle Will India agree to cooperate with China in Nepal's development? Kathmandu: The Diplomat.

Bhola-Paul, H. M. (2015). Tourism Challenges and the Opportunities for Sustainability. Journal of Tourism and Hospitality Management, October, Vol. 3, No. 9-10, doi: 10.17265/23282169/2015.10.004, 204-213.

Budhathoki, A. (2019). China and India Are Fighting Over Nepal's Railways. Kathmandu: Foreign Policy (FP).

Chhetri, T. B. (2018). Federal Democratic Republic Nepal: Deepening Problems and Prospects. Journal of Political Science, Volume XVIII, 2018, 114-142.

Dahal, B. K. (2018). Nepal, India and China: Fostering ties that bind. Kathmandu: The kathmandu Post.

Dahal, G. (2018). Foreign Relation of Nepal with China and India. Journal of Political Science, Volume XVIII, 2018, 46-61.

Jha, H. B. (2013). Nepal's Border Relations with India and China . Eurasia Border Review < BRIT XII > , 63-75.

K.C., K., \& Bhattarai, G. (2018). Nepal's search for prosparity through transit diplomacy. Journal of International Affairs Vol. 2, No. 1, July, 2018, 75-96.

Magar, A. A. (2018). Rs 17 billion new investment in tourism in 2017. Kathmandu: My Republica.

Mahato, G., \& Khanal, A. (2018). Politics, Economics and Leadership in Tourism: An Analysis for Vision 2020 and 2030. Voice of Himalaya: Nepal Mounteneering Association, 21-33. 
MOCTCA. (2019). Nepal Tourism Statistics 2018. Kathmandu: Ministry of Culture, Tourism and Civil Aviation.

MOF. (2018). Economic Survey of Nepal 2017/018. Kathmandu: Ministry of Finance .

MOTCA. (2009). Tourism Vision 2020. Kathmandu: Ministry of Tourism and Civil Aviation.

NPC. (2019). Statistical Pocket Book Nepal, 2018. Kathmandu: Central Bureau of Statistics National Planning Commission.

Pokharel, R., Poudel, J., Sharma, A. R., \& Grala, R. K. (2017). A Study of Climate Variability and Socioeconomic Impact on Tourism Industry of Nepal. Sustainability in Environment Vol. 2, No. 1, $2017,20-34$.

Shrestha, D., \& Jeong, S. R. (2016). An ICT Framework for Tourism Industry of Nepal: Prospect and Challenges. Journal of Internet Computing and Services(JICS) 2016. Dec.: 17(6): 113-122.

Shultz, C. J., Pestek, A., \& Geroulis, E. (2015). Challenges and Opportunities for Development of Sustainable Tourism in Bosnia and Herzegovina. Chicago: Loyola University.

Teker, S., \& Teker, D. (2012). Tourism Projects Financing: A Public-Private-Partnership Model. Business Management Dynamics Vol.2, No.5, Nov 2012, pp.05-11.

Thapa, L. (2018). VNY 2020: Opportunities and challenges. Kathmandu: The Rising Nepal.

WTO. (2015). Affiliate Members' Global Reports, Volume eleven-Public-Private Partnerships: Tourism Development. Madrid: World Tourism Organization .

WTTC. (2019). Travel and Tourism Economic Impact 2019 World. Oxford UK: World Travel and Tourism Council . 